\title{
Leadership in Government High Schools Under RMSA Scheme of Eastern Uttar Pradesh: An Exploratory Study
}

\author{
Sunita Singh ${ }^{1 *}$, Rashmi Pal ${ }^{2}$ and $\mathrm{Kajal}^{2}$ \\ ${ }^{1}$ Assistant Professor, Department of Education, University of Delhi, New Delhi, India \\ ${ }^{2}$ Research Scholar, Department of Education, University of Delhi, New Delhi, India \\ *Corresponding author: nitivasudev@gmail.com
}

Received: $18-09-2021$

Revised: 29-11-2021

Accepted: $12-12-2021$

\begin{abstract}
Teachers are known to be intellectual individuals who continue to teach students in classrooms and have an influence that extends beyond the periphery of classroom space. Leadership is one of the desired qualities of a teacher and the Principal is portrayed as the school leader. Hence, it is imperative to understand the conception of 'leadership' among the school principals. This research study aims to explore the issues and challenges of school leadership among the principals of Government High Schools (GHS) under the RMSA scheme (which is now an integrated part of Samagra Shiksha Abhiyan) in Eastern U.P. The rural areas like Eastern U.P. tend to have the scope of improvement in secondary education and schemes like RMSA promote the access, equity and quality of secondary education. Yet, the quality secondary education in Eastern U.P. is affected by various factors and the conception of leadership of principals plays a significant role in quality attainment of secondary education. The research is qualitative in nature. The purposive sampling was opted. Observations of schools and online consultative meetings held with the principals and teachers of GHS of Eastern U.P. Narrative analysis has been done. Findings suggest they faced challenges due to lack of human and material resources which led to adopting different leadership styles. It was concluded that there is a gap which exists between the ideal conception of leadership qualities and ground realities in the context of Eastern U.P. as the principals were not able to access the required resources which also affect their personal-social interaction towards the goal of holistic development.
\end{abstract}

Keywords: Leadership, GHS, RMSA, School Principal, Challenges

The leader is the person who has the autonomy and authority to lead the group of people of an organization to work towards a specific goal to achieve. Leaders are the one who control and take charge of the operation of an organization (Hao \& Yazdanifard, 2015) and the individuals who apply different strategies for setting optimistic goals and objectives for an organization are known to be the good leaders.

Effective leadership is one of essential skills for an organization to survive and work effectively for the development of the overall institution (Erikson, Edwards, \& Brabant, 2008). So, the organization's quality is very much dependent on the quality leadership. School is also an organization as it involves the head, teachers, other administrative staff and students in a formal setup. It has a vision and also works towards a specific goal. Senge et al. (1999) mentioned that the schools depend on leadership throughout the organization to shape productive futures through a process of selfrenewal.

It is noted that the principal is known to be the school leader who has the authority to work on the school vision. The school principal is one of the

\footnotetext{
How to cite this article: Singh, S., Pal, R. and Kajal. (2021). Leadership in Government High Schools Under Rmsa Scheme of Eastern Uttar Pradesh: An Exploratory Study. Educational Quest: An Int. J. Edu. Appl. Soc. Sci., 12(03): 245-254.
}

Source of Support: None; Conflict of Interest: None 
leaders who instruct teachers and students to move forward with the specific vision of the school and help in fulfilling the aims and goals for which the school works for. It is observed that school principals have many roles to play in school premises such as related to the school head, teacher, authority, and conducts many activities for the school development and leadership skills in students. He/She holds the key position in the school as he is responsible for the school administration and supervision of the personnel involved in the teaching learning process. Everything in the school is supposed to be organized by him or her such as the staff, curriculum transaction, pedagogy, co-curricular activities, school resources etc. He is the organizer, leader, governor, manager, director, coordinator of the school system. The principal is the leader of the group which involves the skills like involving people in a group activity, arrange meetings, initiate various strategies to make the teaching learning process better and implement various pedagogical strategies and make the teachers aware about the contemporary trends for the teaching learning process. "It has become an article of faith that the capacity of schools to improve teaching and learning is strongly mediated by the quality of leadership by head teachers" (Chaudhary, 2002).

The Secondary Education commission (1953) also mentioned "On the headmaster the proper working of the school ultimately depends. The reputation of the school and the position in the society depends in large measure on the influence that he or she exercises. He holds an important place in the life of the community. By contact with parents and the general public he or she can help forge that link between school and the large community." It is observed that the leadership in schools plays a major role in providing the exposure to the students to learn. School leadership is considered as important aspects recognized by the Government of India to develop the school quality by developing the school leadership. The $12^{\text {th }}$ Five year plan ${ }^{1}$ of the Government of India talks about the school leadership as one of the strategic initiatives to improve the learning outcomes (as N. Mythili (2015) also talks about it).

Thus, the present study aims to focus on the school principals as school leaders and issues and challenges faced by them and how they are coping

${ }^{1}$ GOI Planning Commision (2013). up with them through using different leadership styles.

\section{Review of Literature}

Various researches related to school and leadership cited here to understand how leadership affects quality attainment in the school system.

Leadership is known to be an effective method of achieving aims in a group or a team. It is a process where leaders use their skills and knowledge to lead and bring a group of employees in the desired direction that is relevant to their organization's goals and objectives (Jackson and Parry, 2008). So, what is the school is what it does, is determined largely by the intelligence, scholarship, imagination, initiative, personality and social skills of the headmaster or principal.

The uses of the term "school leadership" reflect changes in the role of leaders over the last twenty to thirty years. In many education systems a shift can be observed; from a more administrative and bureaucratic function to one that is more involved in working with teachers and other staff for the improvement of school results (Adams \& Gaetane, 2011; Glatter, 2014; Roach, Smith, \& Boutin, 2010; Spillane \& Kenney, 2012). In schools, leadership is a significant element to cater towards the aims and goals with the vision for which school works. School is one of the organizations where the leaders are born, trained, educated and prepared for further life. The leadership at the school level is often associated with principals, headmasters, power, authority and control (Muhammad et al. 2014).

The role of a leader in schools has been shifted from leading schools with accountability to an organization with collaboration and responsibility (Pont, 2020). The shifts are done in specific contexts, policies, framework of schools and aims and goals of the schools as per the reports of OECD (OECD, 2016). It influenced the role of leadership in schools of India as well. Education was one of the major concerns of the country as it was governed and managed at the national level and further, it was listed in the concurrent list of the country. It was led by traditions of democratic participation, as bureaucratic organizational approach with the government and public collaboration which is also mentioned by Jarl, Frederiksson, \& Persson (Jarl et al. 2012). The principal has the role and 
responsibility of administrator as well as the manager of the school in bureaucratic approach. Teachers worked in isolation from each other and the principal or school leader role was conceived as a bureaucratic administrator or head teacher, or some combination of the two. Pont et al. (2008), as well as Glatter (2014), reflected on how the role evolved from an administrative role in the 1960-80s; to a management role in the 80s and 90s; and finally, to a leadership role since the beginning of 2000 .

Bush et al. (2011) emphasized on the leadership development programmes for school principals as it is necessary to know the importance of leadership who are aspiring to be school principals. Functioning as leaders, principals can serve to transform school cultures or to maintain them (Firestone \& Louis, 1999; Leithwood \& Jantzi, 1999). The principal as a school leader must be providing the positive environment to the teacher to grow as the support of the school leader encourages the teachers to work towards the vision of the school (Birky et al. 2006).

It is important to prepare the idea for teacher leadership and prepare the teachers for it where the principals must be prepared to step into a different type of leadership position (Copland, 2001). Schools depend on leadership to improve their academic performance (Davies, 2005; Spillane, Halverson, \& Diamond, 2004). Moreover, it is significant to expand the horizon of the administrative position which demands that principals are flexible to have a system of shared leadership (Andrews \& Crowther, 2002; Marks \& Printy, 2003). Fullan refers to the need to have collaboration between the principal and teachers for effective working of organisation (Fullan, 2016).

The culture of teacher leadership demands the principal to be understanding and giving the value in constructing the school environment where the teachers are able to exercise the leadership skills in classrooms (Danielson, 2006). Schools and the administration team need to recognize the necessity of the teacher leadership if the schools are to improve (Barth, 2001). Davies (2005) suggested student achievement improves in schools, where principals encourage teacher leadership to emerge in areas important to individual teachers. Barth (2001) also declared that by utilizing teacher leadership, a ripple effect is created that radiates throughout the building as teachers inculcate the leadership skills in the student. Studies such as School Leadership: India at Crossroads (Saravanabhavan \& Karanam; 2016) also show leadership qualities of teachers/principals influence the enrolment rate and achievement of the students in a particular school.

Effective leadership in schools is also needed for school leadership as it leads to develop the school in a holistic manner and gives further chances to explore and develop the school vision within the context in which the school is situated. It does not come in the form of school leader only as it consists of collaboration of the teachers and principals as mentioned by various studies like (Anderson, 2004: Birky, et al. 2006; Danielson, 2006). It is imperative to have an understanding regarding the role of teachers and principals in terms of leadership. Recent research has explored the need and significance of principals and teachers working in a collaborative manner for creating an atmosphere where the students can learn in a better way.

The significance of teachers taking on leadership roles to create trust in the workplace and a bond between the teachers and their colleagues is an important step toward successful school reform (Moller \& Pankake, 2006). In the schools, Principals and teachers reportedly exercised substantial influence in terms of leadership on school practice in matters of curriculum, instruction, and assessment (Marks \& Louis, 1997). School improvement is enhanced by leaders who establish collegial structures that facilitate dialogue and the development of the teachers' voice as a means for developing school goals and visions (Anderson, 2004; Danielson, 2006; Moller \& Pankake, 2006). They both are important and are related to each other as the hierarchical approach is now collaborative leadership rather than one person leading the organization and have the authority and giving instructions to the members of the organization in terms of teaching and learning in schools. This role of collaboration led further to work in a healthy environment to have a way of improvement in schools.

After reviewing many researches, the researchers have a query in mind regarding quality secondary education in terms of leadership in India in the contemporary phase in Eastern U.P. especially where the status of secondary education is not in optimum phase. Secondary education is a terminal 
point to serve students and it also constitutes a critical stage for those aspiring to enter into higher education; secondary education also provides the leadership skills to the educational sector as students who complete secondary schooling can undergo teacher's training. There is a gap which exists in terms of research as leadership in eastern districts of Uttar Pradesh are not mentioned in the field of academia. Thus, it is imperative to study the conception of leadership in principals of secondary schools of Eastern U.P. in terms of quality attainment in secondary education.

\section{Conceptual Background}

In the education system, there were different styles of leadership adopted by the individuals in an organization. Since, individual differences are reflected in the action of the individuals such that principals may also have different ways to adopt the aspects of leadership. Thus, it is an important aspect to explore the dimensions of school leadership (Mythili, 2015). The types of leadership styles identified are shown in Fig. 1.

Leadership Traits required for principal as the leader of the school (Kochar, 2012):

Sharing of leadership with colleagues,

Trust building with professionals,

Provision of support,

Rationality,

Positive attitude towards the goals,

Management of resources,

Collaboration with teachers,

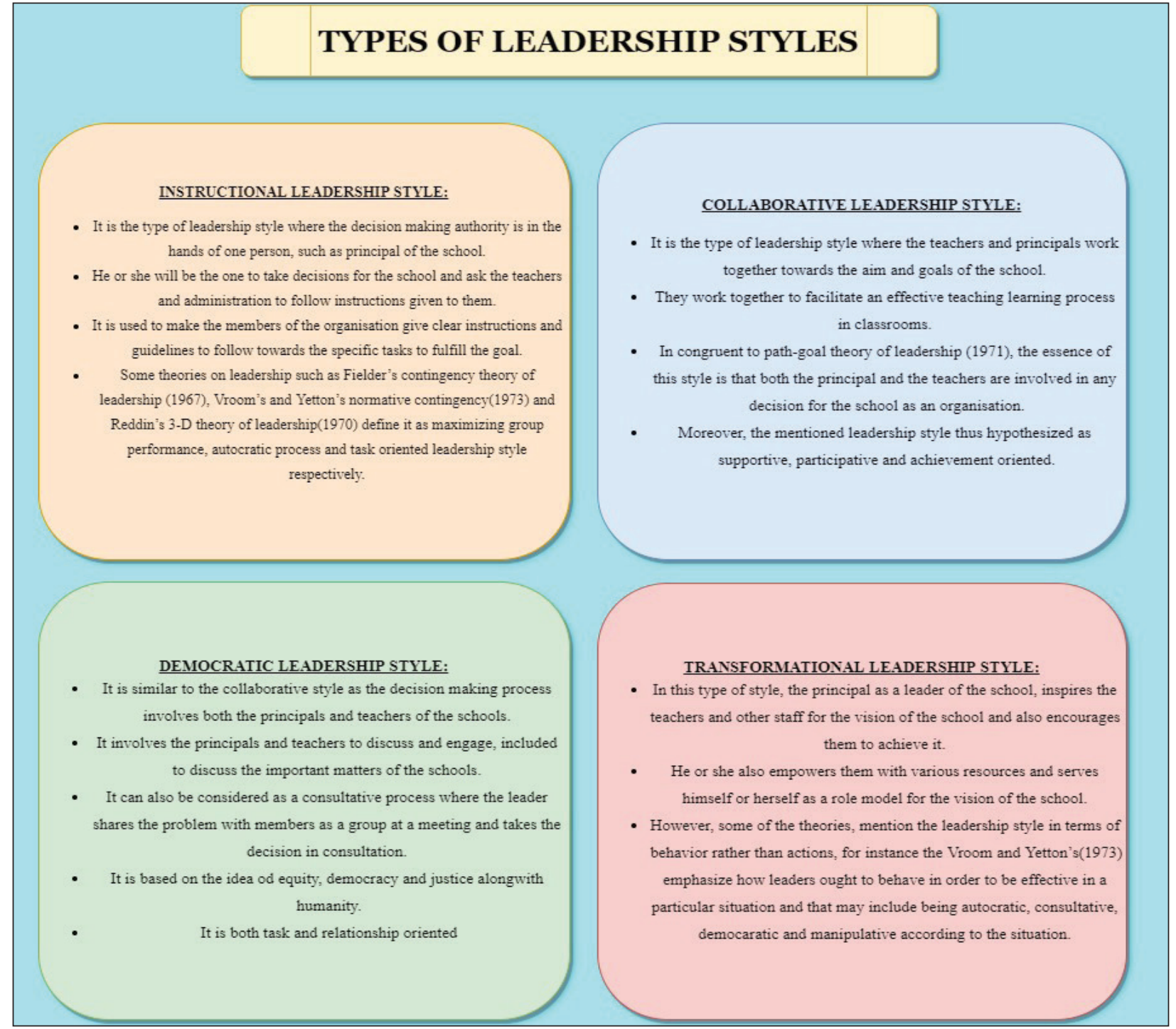

Fig. 1: Types of Leadership 
Supervisory behavior,

Adaptability,

\section{Research Questions}

1. What are the challenges and struggles faced by the principals of Government High School RMSA schools in relation to their leadership?

2. How the availability of principals and teachers and their leadership styles are affecting quality school education in Government High School RMSA?

\section{Objectives of the Research}

To investigate the issues and challenges faced by the school principals in GHS under RMSA Schools in reference to leadership.

To explore the different leadership styles of GHS under RMSA principals which they adapt to cope with issues and challenges in school.

\section{Methodology}

Qualitative research design is opted in the present study. It includes research techniques such as nonparticipating observation schedules and focus group discussions. The samples of the study are School Principals of Eastern Districts such as Pratapgarh, Mirzapur and Sonbhadra of Uttar Pradesh under the scheme of RMSA. The schools are categorized in terms of A, B, and C respectively. The study was done during the month of September to December 2020. The observations and Interview of School principals have been done in RMSA schools of the district Pratapgarh of Eastern Uttar Pradesh. According to Cohen L. et al. (2009), one of the distinctive features of observation as a research process is that it offers the investigators the opportunity to gather live data from naturally occurring social situations. Therefore, it is one of the tools to gather information as first-hand information. Online consultative meetings for Focus Group Discussions with various School Principals and teachers of secondary schools were conducted to understand the conception of leadership among them. Focus group discussion is frequently used as a qualitative approach to gain an in-depth understanding of social issues. The method aims to obtain data from a purposely selected group of individuals rather than from a statistically representative sample of a broader population (Nyumba et al. 2018). The school principals and some teachers (as school principals were not assigned) were interviewed through Focus Group Discussions (FGDs) in online and offline mode through Google meet, Zoom and formal setting. Narrative analysis has been opted for the analysis of the research study. Narrative analysis is a genre of analytic frames whereby researchers interpret stories that are told within the context of research and/or are shared in everyday life. Scholars who conduct this type of analysis make diverse-yet equally substantial and meaningful-interpretations and conclusions by focusing on different elements (Allen, 2017).

Data Collection site: ${ }^{2}$

\begin{tabular}{|c|c|c|c|c|c|}
\hline $\begin{array}{l}\text { Sl. } \\
\text { No. }\end{array}$ & $\begin{array}{l}\overline{0} \\
\text { ठ } \\
\text { ปூ }\end{array}$ & مَّ. & ب。 & 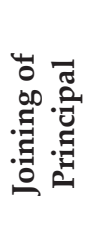 & 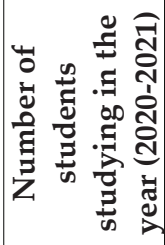 \\
\hline 1 & $\begin{array}{l}\text { Government } \\
\text { High School (A) }\end{array}$ & $\begin{array}{l}\text { Pratapgarh, } \\
\text { U.P. }\end{array}$ & 2012 & 2013 & 142 \\
\hline 2 & $\begin{array}{l}\text { Government } \\
\text { High School (B) }\end{array}$ & $\begin{array}{l}\text { Mirzapur, } \\
\text { U.P. }\end{array}$ & 2010 & 2012 & 105 \\
\hline 3 & $\begin{array}{l}\text { Government } \\
\text { High School (C) }\end{array}$ & $\begin{array}{l}\text { Sonbhadra, } \\
\text { U.P. }\end{array}$ & 2012 & 2015 & 196 \\
\hline
\end{tabular}

\section{RMSA and Secondary education}

Government launched a centrally sponsored scheme for secondary education, Rashtriya Madhyamik Shiksha Abhiyan (RMSA), offering a strategic opportunity to improve access and equity, quality, accountability, ability to measure learning outcomes, and to promote standardization of curriculum and examinations across states. The Rashtriya Madhyamik Shiksha Abhiyan (RMSA) is a process-based, time bound and target oriented program. This has been undertaken by the nation in an Abhiyan mode and it covers all the states and union territories so that the entire population children under the age group of 14 to 18 get the opportunity of climbing the ladder of higher education as well as prepare themselves for improving their life and living. Due to the diversities in culture and tradition as well as heterogeneity in educational status and problems, the plans of RMSA developed by the states/UTs

${ }^{2}$ Principals and teachers were interviewed during observations of schools. The names of principals and teachers are kept confidential by the researchers. 
are highly contextual. RMSA vision envisaged to achieve the secondary school provisions available within a reasonable distance of any habitation, i.e., 5 kilometer for secondary schools and 7-10 kilometers for higher secondary schools, ensuring universal access of secondary education by 2017 (GER of 100\%), universal retention by 2020 and providing access to secondary education with special references to economically weaker sections of the society, the educationally backward, the girls and other marginal categories like SC, ST, OBC and educationally backward minorities.

\section{Findings}

The purpose of this study was to explore the issues and challenges faced by GHS under RMSA School principals in Eastern district of U.P. in terms of leadership and accordingly adopted leadership style. The findings are discussed under two dimensions: concerning issues and challenges of GHS under RMSA School Principals and leadership styles according to the mentioned objectives.

Challenges faced by the GHS under RMSA School (A, B \& C) Principals and their leadership traits:

There are significant challenges found regarding access, equity and quality parameters of RMSA Programme such as the lack of resources in terms of human resources as non-teaching staff, peon, teachers and ICT facilities in the schools.

$\square$ The school building is a good and proper sitting facility, infrastructure such as sanitation facility, female and male toilet, lab and library facility was found in total selected schools.

$\square$ The condition of the library and science lab is near to close or worse due to lack of human resources as regular science teachers and nonteaching staff.

The principals also discussed the various leadership traits needed for the school leader are as follows:

1. Patience

2. Good listener

3. Collaborative

4. Mutual relationship between the teachers and principal

5. Trust building with the stakeholders of the school
6. Shared leadership with the teachers

7. Good decision making skills

8. Rationality for decision

9. Support from the authority

10. Relationship building with the community

The principals further added that there are some conceptions about the leader and leadership skills which need to be addressed as the ground realities are very different from what the books say about the leader. The teachers also agreed with it as one of the teachers of the School (C) mentioned,

"It is difficult to talk about the skills of the leader in the situation as we are the ones who are just handling all by ourselves and yet not getting any resources because of lack of transportation facility and delay in allocation of resources by the authority."

One of the principals (School (B)) said,

"The leader is supposed to lead a team of members, what can we do when there are no teachers and we need to take care of the school".

This statement asserts that in eastern U.P., majority of the GHS principals face challenges as they are not able to share their responsibility due to shortage of staff.

The principal and teachers haven't received any in-service training or workshop. When asked about any leadership program or training they have received, the principal (School (A)) said,

"We haven't received any training or workshop regarding this. It is better to have resources first as they are the main priority for students' learning and there are few grants for the resources".

The leadership styles in GHS under RMSA School Principals are as follows:

\begin{tabular}{|c|c|c|c|}
\hline $\begin{array}{l}\text { Sl. } \\
\text { No. }\end{array}$ & $\begin{array}{l}\text { GHS Under RMSA } \\
\text { Schools of Eastern } \\
\text { Districts (U.P.) }\end{array}$ & $\begin{array}{l}\text { Leadership } \\
\text { Styles }\end{array}$ & $\begin{array}{l}\text { Skills Identified After } \\
\text { Narrative Analysis }\end{array}$ \\
\hline 1 & $\begin{array}{l}\text { Government High } \\
\text { School, Sarainana } \\
\text { Dev, Pratapgarh (A) }\end{array}$ & $\begin{array}{l}\text { Democratic } \\
\text { Leadership } \\
\text { Style }\end{array}$ & $\begin{array}{l}\text { Decision made by } \\
\text { the principal after } \\
\text { discussing with the } \\
\text { staff members } \\
\text { Tasks are divided } \\
\text { into different } \\
\text { sections and are } \\
\text { given to various } \\
\text { stakeholders }\end{array}$ \\
\hline
\end{tabular}




\begin{tabular}{|l|l|l|l|}
\hline 2 & $\begin{array}{l}\text { Government High } \\
\text { School, Chilh Kon, } \\
\text { Mirzapur (B) }\end{array}$ & $\begin{array}{l}\text { Instruction- } \\
\text { al Leader- } \\
\text { ship Style }\end{array}$ & $\begin{array}{l}\text { Principal is taking } \\
\text { decisions on the behalf } \\
\text { of the school } \\
\text { Giving instructions to } \\
\text { the teachers } \\
\text { Teachers are following } \\
\text { the instructions and } \\
\text { mentioning that it is } \\
\text { important to follow } \\
\text { instructions given to } \\
\text { them for the benefit of } \\
\text { the school }\end{array}$ \\
\hline 3 & $\begin{array}{l}\text { Government } \\
\text { High School, } \\
\text { Gothani Chopan, } \\
\text { Sonbhadra(C) }\end{array}$ & $\begin{array}{l}\text { Collab- } \\
\text { orative } \\
\text { Leadership } \\
\text { Style }\end{array}$ & $\begin{array}{l}\text { The principal and } \\
\text { teachers both are taking } \\
\text { part in decision-making } \\
\text { Both the principal and } \\
\text { teacher are dividing } \\
\text { all the tasks within } \\
\text { themselves }\end{array}$ \\
\hline
\end{tabular}

\section{DISCUSSION}

This section deals with the school premises and the principal in terms of their roles and responsibilities as a leader, relationship with teachers, how they take decisions and the challenges they face with the administration for resources of the schools.

\section{(A) Pratapgarh District}

The teachers and principal were both present when the observation was done. The school principal talks about the relationship with the teachers as they both were involved in activities done in the school.

Roles and Responsibilities: The roles and responsibilities of the school leaders in this school include all the administration work which is assigned to the principal in terms of teaching activity and co-curricular activity to be mentioned in the form of school calendar which needs to be maintained for the record. The principal told us that as a leader, it is their duty to organize all the activities and maintain the records to show to the authority.

Relationship with teachers: On questioning how they maintain their relationship with their teachers, the school principal said,

\footnotetext{
"No quality education is possible without good personal relationships. When teachers are treated respectfully, consulted and given responsibility then they respond with better teaching results. I favour establishing democratic relationships with teachers. For this, I assure to give much share in day to day actual administration
}

of the school and it is the duty of the principal to build true rapport within the staff through informal and formal communication. When we talk about cooperation from the staff, it is important that the school principal skillfully assist the staff members to improve their competence in making their contribution as well as to gain competence in working together with others on specific assignments."

When the principal was asked about the leadership and skills associated with it, the principal said that "the leader is the one person who knows about the school in a whole manner". It is also necessary to know about the skills of the teacher as we can improve their skills further. The teachers also have the self-confidence to teach in different manners and also willing to try new strategies to inculcate the leadership in the students.

Challenges while exercising leadership: The issue is that it is difficult to manage the resources as the lab facilities for the science classroom are not in ample amounts. As a leader, the principal felt helpless,

\section{"We can't do anything about it. The resources are not allocated to the schools and sometimes when we ask the authorities for the resources, we can't get any response from the authorities".}

In relation to roles and responsibility for the community and general public, the principal answered that we have good cooperation with the surrounding community and we always create opportunities in the school to invite the community person in the form of parents and as a resource to keep touch with them. When asked about what kind of qualities they feel necessary to have a happy relationship with a community person, the principal answered, "patient listening to the community and what they want to communicate is important in rural areas".

Decision-making: When asked about decision making through observations and focus group discussion, the principal said,

\footnotetext{
"We take decisions after discussions. I normally discuss with the staff members like teachers, assistant teachers and then take a final call for any activity which is to be organised in school".
}

In many of the research findings also, the same results are cited here as it was observed that the principal and teachers share responsibility for staff development, curricular development, 
and supervision of instructional tasks. Thus, the principal is not the sole instructional leader, but the "leader of instructional leaders" (Glickman, 1989). It is also noted that the Teacher perspectives on teacher leadership should be changed to improve school performance in general. Teachers who show self-confidence can improve teaching practice (Ware \& Kitsantas, 2007).

\section{(B) Mirzapur District}

The principal went to the DIOS Office for the report and other administration work and the teachers were present when the observation was done.

Roles and Responsibilities: The principal expressed her views in an online meeting about the roles and responsibilities of the school leader,

"As a school principal I need to prepare a school calendar in which they mention details of different courses, co-curricular activities, school timings, list of holidays, compilation of teaching courses etc."

Challenges while exercising leadership: As a School principal, the principal of the school expresses their views regarding information transactions to the DIOS office. The principal said. "it is difficult to manage school daily routine and to go to the same day to give them information regarding admission or other issues in the absence of any non-teaching staff and teachers. At district level DIOS office is established in the main city but RMSA schools are in rural areas sothe distance covered by them to reach city office is approx. more than $30 \mathrm{~km}$ on one side".

So, for a principle, it is a major issue to have a connection with administration. The responsibilities of non-teaching staff were also done by the principals. The principal said, "It was difficult to manage because of the delay in resources allocated to the school for students learning as it sometimes took months for equipment or desks or any classroom material resource to arrive in rural areas like eastern districts of U.P."

As he cited the example of how the parents misbehave some time with him regarding many issues but as a principal his work is to balance the demand of parents or opinion of the public, perception of the teacher and aspiration of the students.

Relationship with teachers: The relationship with the teachers is friendly and they always follow the instructions given to them. One of the teachers said,
"As the principal of the school knows how to lead a team in different situations, it is always a huge task and responsibility for the school leader, so we as a team should stick together to support our leader."

The principal said,

"I ask the teachers what can be done further to improve the teaching learning process so that the students are able to understand better and can use their knowledge for the society. We always discuss the activities which can be done to improve the school in every aspect".

It was further added that sometimes, the instructions are given to the students and teachers to follow and participate in the activity for an occasion and planned by the principal. It can be observed that it is the type of instructional leadership in which the principal is giving instructions to follow and work on a task. It is noted that within school premises, the principal seeks out the ideas, insights and expertise of teachers in these areas and works with teachers for school improvement (Marks \& Printy, 2003).

\section{(C) Sonbhadra District}

When the observation was done, the principal was there and only one teacher was there in the school. They both were managing all the administration work with the teaching and learning of the students.

Roles and Responsibilities: The roles and responsibilities include all the tasks to be done as the school leader as the principal told,

\footnotetext{
"We do all the work by ourselves. It includes administration work and resources to be provided for the students as the resources are in school sometimes and we don't have lab facilities which also count in the task of school leader. The tasks are to maintain school records as student absenteeism, admission detail, exam detail, category wise distribution of students in each class, purchase records, library records, school time table, distribution of work teaching and non-teaching etc."
}

As school had only one teacher for all the classes, the principal also needed to teach the students and sometimes, they needed to enroll them by going to their homes and also fulfill the staff duties including preparing the list and others. It further indicated that the principal's teachers wish to have more teachers as human resources to collaborate 
in terms of responsibility when it comes to teacher leadership roles.

Challenges while exercising leadership: As shared by the principal in RMSA school,

"There are so many issues faced by me to reach the school which is in rural areas such as lack of transportation facilities". It was further added, "It covers approx. $3 \mathrm{~km}$ each day through foot in 2018, now, we have a female teacher in school and we both come here from the scooty. So, lack of proper transportation facility, good roads is also a problem".

The relationship with the teachers is in collaboration with the leader of the school. As there is a principal and only one teacher to conduct all the activities and teach the students, both the principal and teacher share all the roles and responsibilities of the school administration. As the teacher and principal both agreed on it and told,

\begin{abstract}
"We always take decisions by discussing it with each other. The leadership is not just about leading a team, it is also a collaboration of the teachers and principal to work towards the same goal. The school is for everyone and everyone has the right to take decisions on behalf of the stakeholder of the school".
\end{abstract}

These individuals recognize teachers as equal partners in this process, acknowledging their professionalism and capitalizing on their knowledge and skills (as mentioned by Darling-Hammond, 1988; Rowan, 1990 also). It can be said that shared leadership is observed as it involves the active collaboration of principal and teachers on curriculum, instruction and assessment in RMSA schools.

\section{CONCLUSION}

In eastern U.P., the quality secondary education suffers due to unavailability of teachers, principals and infrastructure facilities such as ICT, Lab facilities etc. Yet, most of the principals are satisfied by integration of the GHS School in Samagra Shiksha Yojana as they will be promoted as the school principal of senior secondary school and then facilitate holistic quality secondary education. This study also concludes that school principals need an in-service teacher training programme in relation to leadership and they demand availability of different regular pedagogy teachers and other staff in GHS under RMSA Schools as the enrollment and retention rate in GHS Schools decreased from the establishment to current academic year. It is also concluded that the school principal and teachers need community support in relation to their participation in the school management committee. It is noted that the principals of different schools adopted different leadership styles according to their school contexts such as lack of resources, teachers' accountability and decision-making skills.

Researchers noticed the gap between the ground reality in the field and theoretical conception of leadership because the principals were not able to exercise the leadership effectively due to lack of resources which ultimately affect their own personal-social interaction towards the goal of holistic development.

Researchers suggest the promotion of leadership in education is needed to attain quality parameters in Eastern U.P. Schools. Many steps needed to be taken for instance, providing the resources and lab facilities at time to the students and allocation of the administration staff and teachers in the schools for a holistic development and making the school a better learning place to have young students to learn in a better way.

\section{REFERENCES}

Adams, C. and Gaetane, J. 2011. A diffusion approach to study leadership reform. Journal of Educational Administration, 49(4): 354-377.

Anderson, K.D. 2004. The nature of teacher leadership in schools as reciprocal influences between teacher leaders and principals. School Effectiveness and School Improvement, 15(1): 97-113.

Andrews, D. and Crowther, F. 2002. Parallel leadership: A clue to the contents of the "black box" of school reform. The International Journal of Educational Management, 16(4): 152-159.

Angelle, P.S. and DeHart, C.A. 2011. Teacher Perceptions of Teacher Leadership: Examining Differences by Experience, Degree, and Position. National Association of Secondary School Principals Bulletin, 95: 141-160.

Barth, R. 2001. Learning by heart. San Francisco: Jossey-Bass.

Birky, V.D., Shelton, M. and Headley, S. 2006. An administrator's challenge: Encouraging teachers to be leaders. National Association of Secondary School Principals Bulletin, 90(2): 87-101.

Bush et al. 2009. The Zenex ACE: School Leadership Research: Final Report. Pretoria: Department of Education. 
Cabeza-Erikson, I., Edwards, K. and Van Brabant, T. 2008. Development of leadership capacities as a strategic factor for sustainability. Karlskrona: Blekinge Tekniska Höogskola.

Copland, M.A. 2001. The myth of the super principal. Phi Delta Kappan, 82(7): 528- 533.

Danielson, C. 2006. Teacher leadership: That strengthens professional practice. Alexandria, VA: Association for Supervision and Curriculum Development.

Davies, B. 2005. The essentials of school leadership. Thousand Oaks, CA: Sage.

Fiedler, F.E. 1967. A theory of leadership effectiveness. New York: McGraw-Hill.

Firestone,W.A. and Louis, K.S. 1999. Schools as cultures. In: J. Murphy \& K. S. Louis (Eds.), Handbook of research on educational administration ( ${ }^{\text {nd }}$ ed., pp. 297-322). San Francisco: Jossey-Bass.

Glatter, R. 2014. Educational administration 1969-2014: Reflections on pragmatism, agency and reform. Journal of Educational Administration and History, 46(3): 351-366.

Government of India, 2009.https://www.india.gov.in/spotlight/ rashtriya-madhyamik-shiksha-abhiyan\#tab=tab-1

House, R. 1971. A Path Goal Theory of Leader Effectiveness. Administrative Science Quarterly, 16(3): 321-339.

Jackson. and Parry. 2008. A Very Short, Interesting and Reasonably Cheap Book About Studying Leadership. London: SAGE Publication, 208(2): 25.

Jarl, M., Frederiksson, A. and Persson, S. 2012. New public management in public education: A catalyst for the professionalisation of school principals in Sweden. Public Administration, 9(2): 429-444.

Kochar, S.K. 2012. School Administration and Management. Sterling Publishers. New Delhi.

Leithwood, K., Jantzi, D. and Steinbach, R. 1999. Changing leadership for changing times. Philadelphia: Open University Press.

Marks, H.M. and Printy, S.M. 2003. Principal Leadership and School Performance: An Integration of Transformational and Instructional Leadership. Educational Administration Quarterly, 39(3): 370-397.

Moller, G. and Pankake, A. 2006. Lead with me: A principal's guide to teacher leadership. New York: Eye on Education.
Muhammad Faisal, A.G., Norfariza, M.R., Shahril Charil, M. and Faisol, E. 2011. Pengenalankepada Amalan Kepimpinan Guru di Malaysia: Cabarandan Cadangan. Management Research Journal, 3: 71-92. (n.d.).

Mythili, N. 2015. School Leadership Development Programme-A Road Map for Andhra Pradesh. Journal of Educational Planning and Management, pp. 379-400. NIEPA. New Delhi.

Narrative Analysis. 2017. The SAGE Encyclopedia of Communication Research Methods. DOI: 10.4135/97814 83381411.n368

OECD. 2016. School leadership for learning: Insights from TALIS 2013. Paris: OECD Publishing.

Onyumba, T., Wilson, K., Derrick, C.J. and Mukherjee, N. 2018. The use of focus group discussion methodology: Insights from two decades of application in conservation. Methods in Ecology and Evolution, 9(1): 20-32.

Pont, B., Nusche, D. and Moorman, H. 2008. Improving school leadership Vol 1: Policies and practices. Paris: OECD Publishing.

Pont, B. 2020. A literature review of school leadership policy reforms. Eur. J. Educ., 55: 154-168.

Reddin, William J. 1970. Managerial Effectiveness. New York: McGraw-Hill.

Roach, V., Smith, W. and Boutin, W. 2010. School leadership policy developments and trends: Between policy expedience or policy excellence? Educational Administration Quarterly, pp. 1-20.

Senge, P., Cambron-McCabe, N., Lucas, T., Smith, B., Dutton, J. and Kleiner, A. 2000. Schools that learn: A fifth discipline field-book for educators, parents, and everyone who cares about education. New York: Doubleday/Currency.

Spillane, J. and Kenney, A. 2012. School administration in a changing education sector: The US experience. Journal of Educational Administration, 50(5): 541-561.

Spillane, J., Halverson, R. and Diamond, J. 2004. Towards a theory of leadership practice; A distributed perspective. Journal of Curriculum Studies, 36(1): 3-34.

Vroom, V.H. and Yetton, P.W. 1973. Leadership and decisionmaking. Pittsburgh: Pittsburgh University Press. 